ks. Szymon Fedorowicz

\title{
Nieznane kolektarze kartuzów
}

W Bibliotece Ojców Dominikanów w Krakowie znajdują się dwa niezwykłe kolektarze ${ }^{1}$. Należały one niegdyś do kartuzów mieszkających w nieistniejącym już klasztorze w Gidlach i stamtąd pochodzą. Warto poświęcić im nieco uwagi. Obie księgi są bardzo podobne, chociaż napisane inną ręką, zupełnie innym pismem, na nieco innym papierze, ale za to takim samym czarnym inkaustem. Rękopis 84L ma pismo staranne, ale odręczne, niemal szkolne, zaś $85 \mathrm{~L}$ ma pismo bardzo przypominające druk. Rubryki w 84L napisane są tym samym inkaustem, co pozostałe teksty, zaś pierwsze litery całych formuł przycieniowane są na czerwono. W 85L wszystkie rubryki mamy pisane czerwonym inkaustem, jak również wszystkie pierwsze litery modlitw. Rozmiary obydwóch ksiąg są niewielkie: $200 \times 250 \mathrm{~mm}$, a objętość: jedna liczy stron 123, a druga XXXVII + 81, czyli 118 .

Księgi z całkowitą pewnością powstały w gidelskim klasztorze, a autorami musieli być zakonnicy. Wskazują na to informacje zawarte w obydwóch rękopisach. Otóż pod datą 6 października w kalendarzu liturgicznym księgi 84L umieszczone jest imię św. Brunona, a w sanctorale - tak 84L, jak i 85L - znajdują się modlitwy ku jego czci. Święty ten, który zmarł 6 października 1101, był założycielem kartuzów. Zakon ten powstał w 1084 roku przez odłączenie się od kamedułów ${ }^{2}$ niewielkiej grupy eremitów, którym przewodził właśnie św. Bruno. Zorganizował on w alpejskiej miejscowości Chartreuse nowy klasztor. Jego imię zostało mocno wyeksponowane przez zapisanie go w kalendarzu wielkimi literami. Natomiast w proprium sanctorum rękopisów pod datą 6 października same zapisy są bardziej rozbudowane: „S. Patris nostri Brunonis Patriarche ordinis Carthusiensis” (84L), „In Solennitate S. P. N. Brunonis” (85L), a skrót oznacza „Sancti Patris Nostri”3.

\footnotetext{
${ }^{1}$ Sygnatury $84 \mathrm{~L}, 85 \mathrm{~L}$.

${ }^{2} \mathrm{~W}$ kalendarzu księgi 84L pod datą 7 lutego umieszczone jest imię św. Romualda, opata, założyciela kamedułów.

${ }^{3}$ Uroczystość św. Brunona miała u kartuzów oktawę (13 X): „In octavis S. P. N. Brunonis” (84L). Księga 84L zawiera modlitwy na dni w oktawie (w niedzielę w oktawie brano oficjum z uroczystości), s. 111; również 85L ma: „In octavis sancti Patris nostri Brunonis sicut die”, s. 59.
} 
Z kalendarza możemy również zaczerpnąć informacje na temat czasu powstania kolektarzy. Pod datą 5/6 marca umieszczono zapis upamiętniający rocznicę śmierci Zuzanny z Przeręb Oleskiej, która zmarła w 1662 roku Księgi powstały, rzecz jasna, już po tej dacie. Ufundowała ona klasztor kartuzów w Gidlach w 1641 roku, sprowadzając ich z kaszubskich Kartuz ${ }^{5}$. Rozszerzenie kultu św. Brunona na cały Kościół - chociaż nigdy nie był on oficjalnie kanonizowany - miało miejsce w roku 1623. Ale w samym zakonie czczono go już od 1514 roku, dlatego też jego imię nie może być tu dla nas punktem odniesienia. Ale mogą nim być znajdujące się w kalendarzu imię św. Franciszka Salezego, który kanonizowany był w 1665 roku, uroczystość Imienia Jezus zamieszczona pod datą 15 stycznia, rozciągnięta na cały Kościół z franciszkańskiego kalendarza w 1721 roku, uroczystość Boleści (Compassio) Matki Bożej ${ }^{6}$ wpisana do kalendarza liturgicznego w 1727 roku, a zwłaszcza obchód św. Jana Nepomucena, którego kult jako błogosławionego zatwierdzono w 1721 roku, a wyniesionego na ołtarze przez kanonizację w 1729 roku. Z drugiej strony, w kolektarzu 85L została doklejona ${ }^{7}$ kartka z wydrukowanymi elementami oficjum na uroczystość Najświętszego Serca Jezusa, które - jak wiadomo - zostało w Kościele w Polsce wprowadzone w 1765 roku. Wynika z tego, że obydwie księgi powstały między 1727/1729 a 1765 rokiem $^{8}$. I w tym czasie były używane?!

${ }^{4}$ Stownik geograficzny Królestwa Polskiego, pod red. F. Sulimierskiego, Warszawa 1881, t. 10, s. 544, podaje datę śmierci Zuzanny Oleskiej: 8 III 1662.

${ }^{5}$ Zob. H. GAPSKI, J. ZwiązeK, Gidle, [w:] Encyklopedia katolicka, t. 5, Lublin 1989, k. 1057; Encyklopedia kościelna, pod red. M. Nowodworskiego, Warszawa 1877, t. 10, s. 132, podaje, że fundatorka życzyła sobie założenia klasztoru w Babiu i że pod tym warunkiem zapisała dobra kartuzom z Paradyża na Pomorzu. Jednak z nieznanych przyczyn zbudowano go w Gidlach. Klasztor został skasowany w 1819 roku, choć zakonnicy pozostali w nim do końca życia. Ostatni z nich zmarł w 1839 roku.

${ }^{6}$ Kościół kartuzów w Gidlach miał wezwanie Matki Bożej Bolesnej i takie pozostaje aż do dnia dzisiejszego.

${ }^{7}$ Między stroną 36 i 37.

${ }^{8} \mathrm{~W}$ roku 1754 miało miejsce poświęcenie nowo wybudowanego barokowego kościoła klasztornego. Mogłoby to stanowić okoliczność sprzyjającą i uzasadniającą wykonanie nowych ksiąg liturgicznych. W kalendarzu (84L) znajdują się dwie interesujące notatki, które mogłyby rzucić jeszcze więcej światła na czas powstania ksiąg, aczkolwiek są to notatki bardzo tajemnicze: 1 - „Circa principium Martii fit Tricenarium Reginae Franciae”, s. 6; 2 - „Circa festum s. Marci fit Tricenarium Domini Amblardi”, s. 9. Brak daty rocznej czyni takie informacje mało użytecznymi dla naszych poszukiwań. Ale jeśli wziąć pod uwagę, że w tym czasie królową Francji była żona Ludwika XV, Polka, Maria Leszczyńska (1703-1768), która koronowana była w roku 1725 , wówczas 30 . rocznica wstąpienia na tron wypadałaby w 1755 roku. Gdyby jedna z naszych ksiąg miała powstać na okoliczność poświęcenia kościoła kartuzów w Gidlach, taki zapis byłby wytłumaczalny, mimo że uzasadnienie sprawia nam pewne trudności (dlaczego królowa Francji zasługiwałaby na szczególną pamięć gidelskich kartuzów?). Postać Amblarda pozostaje tajemniczą, choć mógłby to być któryś z przełożonych 
W części zawierającej kolekty i kapitula - tak temporale ${ }^{10}$, jak i sanctorale $^{11}$ - manuskrypty różnią się minimalnie. Inne natomiast są ich dodatki, które umieszczone są zarówno na początku obydwóch ksiąg, jak i na ich końcu. Kolektarz 84L posiada kalendarz liturgiczny (s. 1-26), którego brak w 85L. Natomiast 85L ma na początku indeks zawartości księgi, ale wyraźnie niedokończony, obejmujący tylko siedemdziesiąt cztery strony. Na stronach numerowanych od I do XXXVII tego kolektarza umieszczone są zakonne obrzędy wiatyku, ostatniego namaszczenia, modlitwy odmawiane przy umierającym oraz obrzędy pogrzebu z tekstami przeznaczonymi do śpiewu z nutami. Ponadto cztery formy absolucji: osób spowiadających się zwyczajnie (in quotidianis confessionibus), podejmujących spowiedź generalną (in generalibus confessionibus), na okoliczność przypadków zarezerwowanych (a casibus reservatis) i w przypadku bliskiego niebezpieczeństwa śmierci (in articulo mortis).

Obydwa kolektarze posiadają teksty dwunastu błogosławieństw udzielanych przed czytaniami lekcji. Ale podczas gdy rękopis 84L ma błogosławieństwa na trzy nokturny (s. 27), to 85L przewiduje je najpierw na matutinum niedziel i świąt z XII lekcjami (dwa ostatnie na Boże Narodzenie są odmienne od pozostałych), a następnie na dni powszednie, a ponadto przed czytaniem Ewangelii ${ }^{12}$. W kolektarzu 84L następują teraz (s. 32) błogosławieństwa stołu, a dokładniej pokarmów przed drugim śniadaniem i wieczerzą, oraz modlitwy po posiłku. Te same modlitwy są w 85L, ale umieszczone w końcowej jego części (s. 71). Obydwa też mają modlitwy ad Primam Capitulum ${ }^{13}$, które przewidują na niedziele i święta z XII lekcjami, w oktawie Bożego Narodzenia, Wielkanocy i Zesłania Ducha Świętego fragment z Listu do Tymoteusza, zaś na niedziele adwentu, niedziele i święta z XII lekcjami w wielkim poście i na wigilię Bożego Narodzenia urywek rozdziału 33 z Księgi Proroka Izajasza. Rękopis 85L ma ad Primam Capitulum z dodatkowymi, odpowiednio dobieranymi modlitwami za zmarłych i chorych, ale również ad Sextam, ad Nonam

tamtejszej wspólnoty zakonnej albo po prostu jeden z jej członków, którego rocznica święceń lub ślubów przypadała właśnie tego samego roku. Przyznać wreszcie trzeba, że zapisy tego rodzaju świadczą o ograniczonej perspektywie ich autora.

${ }_{9}^{9}$ Jest to stwierdzenie zaskakujące, skoro kolektarze - choć jeszcze sporządzane były gdzieniegdzie w pierwszej połowie XVI wieku - wyszły z użycia z chwilą wprowadzenia jednolitych ksiąg liturgicznych po soborze trydenckim. Można jednak przypuszczać, że przypadek klasztoru gidelskiego nie był odosobniony. Świadczy o tym choćby przechowywany w Bibliotece Narodowej w Warszawie, dominikański kodeks pochodzący z XVI wieku, ale uzupełniany właśnie jeszcze w XVIII (Rkps Zam. 207).

${ }^{10}$ 84L: s. 50-76, 85L: s. $17-36$.

${ }^{11}$ 84L: s. 76-120, 85L: 36-63.

${ }^{12} \mathrm{~S}$. 1. Część kolektarza 85L zaczynająca się od tej strony ma tytuł Usus ferialis i modlitwy w niej zawarte przeznaczone są na każdy dzień wszystkich godzin kanonicznych.

${ }_{13}^{3}$ 84L: s. 37, 85L: s. 7. 
i ad Vesperas na niedziele i dni powszednie. W tych godzinach mniejszych podane są kapitula i tylko incipity pozostałych modlitw. Nie powtarza się już długich modlitw z ad Primam, ale bierze się preces maiores (odmawiane po drugim nokturnie w dni powszednie), które podane są wcześniej (s. 4-7). Rękopis 84L również je przewiduje w tym miejscu i po modlitwie ad Primam podaje preces przeznaczone na wszystkie godziny kanoniczne (s. 46-50).

Zasadnicza treść kolektarza, to znaczy kolekty i kapitula przeznaczone na poszczególne godziny kanoniczne, w obydwóch naszych rękopisach podzielona jest na dwie części: teksty przewidziane na czas w ciągu roku - temporale i teksty wykorzystywane w dni poświęcone obchodom świętych - sanctorale. Zarówno temporale jak i sanctorale w niewielkim stopniu przypominają pełne i bogate zestawy tekstów z dawnych kolektarzy średniowiecznych. Są bardzo skromne, ograniczone nieraz do jednej tylko formuły na dany dzień; dużo w nich skrótów i odsyłaczy. W ubogim sanctorale jest niemal regułą odsyłanie do tekstów z commune sanctorum.

Manuskrypt 84L rozpoczyna pierwszą część od 1 niedzieli adwentu (ściślej, od nieszporów w sobotę, s. 50) i na niej poprzestaje, gdy chodzi o ten okres, dodając kolektę i kapitula poszczególnych godzin na dni powszednie. Podobnie jest w 85L (s. 17), gdzie niedziele w ogóle potraktowane są zbiorowo, tak samo zresztą jak i dni powszednie. Dni w oktawie Bożego Narodzenia są wyszczególnione, ale 85L używa określenia solennitas na dni św. Szczepana, św. Jana, św. Niewiniątek, zaś festum na dzień św. Tomasza. W tej części znajduje się uroczystość Imienia Jezus, którą w klasztorze gidelskim obchodzono w niedziele po oktawie Epifanii ${ }^{14}$.

Podobnie ma się rzecz z okresem wielkiego postu. Takie same teksty mają wszystkie niedziele do de Passione, takie same teksty mają też dni powszednie tego okresu. Po tej niedzieli teksty się zmieniają, ale i tu jednolite są aż do Wielkiego Czwartku. W piątek przed Niedzielą Palmową obchodzi się Compassio Matki Bożej. Dni w oktawie Wielkanocy niczym się nie różnią. W okresie wielkanocnym też każda niedziela ma te same teksty, podobnie jak i dni powszednie. W tym przypadku analogiczną do de Passione cezurę stanowi uroczystość Wniebowstąpienia Pańskiego. Natomiast w ogóle nie ma żadnych tekstów ani na niedziele, ani na dni powszednie po uroczystości Trójcy Świętej. Uroczystość Najświętszego Serca Jezusa została wprowadzona do księgi 85L już po jej napisaniu, jak to już wcześniej wspomniano.

Jeszcze bardziej skrótowo potraktowano sanctorale w obydwóch kolektarzach rozpoczynających tę część księgi nie - jak to na ogół bywało - od św. Andrzeja, ale od św. Saturnina z dnia 29 listopada. Wszystkie obchody

${ }^{14}$ 84L: s. 2, 85L: s. 26. 
świętych mają podane daty dzienne. Znajdujemy tam imiona świętych, którzy zostali wyniesieni na ołtarze już w czasach nowożytnych, między innymi: 29 stycznia - św. Franciszka Salezego (kanonizowanego w 1665), 4 marca -św. Kazimierza (kanonizowanego w 1602), 16 maja - św. Jana Nepomucena (kanonizowanego w 1729), 31 lipca - św. Ignacego Loyoli (kanonizowanego w 1623), 15 października - św. Teresy Wielkiej (kanonizowanej w 1622). Ale większość tekstów należy zaczerpnąć z commune sanctorum, o czym informują odpowiednie zapisy. Szczególnie uderzające jest to w manuskrypcie $85 \mathrm{~L}^{15}$. Modlitwy wspólne (commune) następują zaraz po sanctorale. W rękopisie 84L brakuje ostatnich stron, dlatego też commune są niepełne (s. 120-123), natomiast w 85L są kompletne (s. 63-68). W jego końcowej części znajdują się następujące dodatkowe elementy: Agenda defunctorum (modlitwy za zmarłych na nieszpory, nokturny i laudesy, s. 68), błogosławieństwo stołu (s. 71), modlitwy quando fiunt opera communia - na cmentarzu (s. 73), preces pro priore eligendo (modlitwy o wybór przeora), preces minores (te same, co na stronach 4-7, s. 74), modlitwy podczas pogrzebu: w drodze na cmentarz, przy rozkopanej mogile po przyniesieniu zmarłego, przy składaniu zmarłego do grobu, przy zasypywaniu mogiły i przy jego grobie (s. 77-81).

Nie wiadomo, jaki był powód sporządzenia dwóch tak podobnych ksiąg w tym samym mniej więcej czasie. Można przypuszczać, że zadecydowały o tym jakieś względy praktyczne, których nie sposób już teraz określić. Zredagowanie ich na potrzeby jednej tylko wspólnoty tłumaczyłoby natomiast to, że są rękopisami, a nie drukami, ale jednocześnie wskazywałoby na jej szczególne zwyczaje liturgiczne. Tak czy inaczej, w pewnej mierze uzupełniają się, zwłaszcza gdy chodzi o rozmaite dodatki. Wyraźnie jednak widać, że znaczenie kolektarza jako księgi chórowej było wówczas we wspólnocie kartuskiej niewielkie, choć i tak zdumiewa fakt, że jeszcze był on w użyciu, a - co więcej - nawet specjalnie był sporządzany w epoce przecież od dawna drukowanych już brewiarzy. Biorąc pod uwagę stosunkowo liczne dodatki zamieszczone w kolektarzach gidelskich, wolno sądzić, że służyły one wspólnocie zakonnej bardziej jako agendy, podręczniki do nabożeństw, tudzież swoiste modlitewniki, niż jako istotna księga przeznaczona do odmawiania modlitw liturgii godzin ${ }^{16}$. Wszystko to, co można o nich powiedzieć, świadczy o ich oryginalności i wyjątkowości.

Kraków

KS. SZYMON FEDOROWICZ

${ }^{15} \mathrm{~W}$ tym rękopisie pod datą 24 czerwca (s. 47) znajduje się późniejszy dopisek sporządzony inną ręką: „Pro anniversario Domini Rykalski”, co oznacza rocznicę śmierci kapłana noszącego to nazwisko. Potwierdza to notatka odsyłająca Ad Agendam i polecająca zastosowanie podanych tam modlitw za zmarłych, między innymi pro sacerdote.

${ }^{16}$ Warto zauważyć, a nawet podkreślić, że nie są znane żadne inne tego typu księgi pochodzące od polskich kartuzów. 


\section{Résumé}

\section{Les collectaires inconnus des chartreux}

Dans la bibliothèque du monastère dominicain à Cracovie se trouvent deux collectaires qui viennent d'une déjà inexistante chartreuse de Gidle. Ils étaient crées dans la 2 ${ }^{\text {ème }}$ moitié du XVIII siècle. On ne sait pas pour quelle raison on réalisait ces deux manuscrits si semblant, presque à la même époque. On peut deviner que certains éléments pratiques en décidaient, sans qu'on puisse les déterminer aujourd'hui. Leur rédaction pour le besoin d'une seule communauté expliquerait le fait que ce sont des manuscrits, mais au même temps cela indiquerait des coutumes liturgiques particulières. D'une certaine manière, ils se complètent, surtout qu'il s'agit de différents suppléments. On voit clairement que l'importance du collectaire comme un livre de choral était mineure chez les chartreux, alors, il est étonnant qu'il ait été encore en utilisation. De plus, ils étaient préparés exprès dans l'époque où les bréviaires depuis longtemps étaient déjà imprimés. En tenant compte de nombreux suppléments placés dans les collectaires on s'autorise de penser qu'ils servaient à la communauté monastique plutôt comme des agendas, des manuels de liturgie ou des livres de prière, que réels livres destinés à réciter des prières de la liturgie des heures. Tout ce qu'on peut en dire témoigne de leur exception et de leur originalité. 